\title{
Development of human antibody fragments using antibody phage display for the detection and diagnosis of Venezuelan equine encephalitis virus (VEEV)
}

\author{
Martina Inga Kirsch ${ }^{\dagger 1}$, Birgit Hülseweh ${ }^{\dagger 2}$, Christoph Nacke ${ }^{1}$, Torsten Rülker ${ }^{1}$, \\ Thomas Schirrmann ${ }^{1}$, Hans-Jürgen Marschall ${ }^{2}$, Michael Hust ${ }^{* \dagger 1}$ and \\ Stefan Dübel ${ }^{\dagger 1}$
}

Address: ${ }^{1}$ Abteilung Biotechnologie, Institut für Biochemie und Biotechnologie, Technische Universität Braunschweig, Spielmannstraße 7, 38106, Braunschweig, Germany and ${ }^{2}$ Armed Forces Scientific Institute for Protection Technologies - NBC Protection (WIS), Humboldtstraße 1, 29633, Munster, Germany

Email: Martina Inga Kirsch - martina.kirsch@tu-bs.de; Birgit Hülseweh - birgithuelseweh@bwb.org;

Christoph Nacke - christoph.nacke@gmx.de; Torsten Rülker - t.ruelker@tu-bs.de; Thomas Schirrmann - th.schirrmann@tu-bs.de; Hans-

Jürgen Marschall - hansjuergenmarschall@bwb.org; Michael Hust* - m.hust@tu-bs.de; Stefan Dübel - s.duebel@tu-bs.de

* Corresponding author †Equal contributors

Published: 2 September 2008

BMC Biotechnology 2008, 8:66 doi:10.1 186/1472-6750-8-66

This article is available from: http://www.biomedcentral.com/1472-6750/8/66

(C) 2008 Kirsch et al; licensee BioMed Central Ltd.

This is an Open Access article distributed under the terms of the Creative Commons Attribution License (http://creativecommons.org/licenses/by/2.0), which permits unrestricted use, distribution, and reproduction in any medium, provided the original work is properly cited.
Received: 16 December 2007

Accepted: 2 September 2008

\begin{abstract}
Background: Venezuelan equine encephalitis virus (VEEV) belongs to the Alphavirus group. Several species of this family are also pathogenic to humans and are recognized as potential agents of biological warfare and terrorism. The objective of this work was the generation of recombinant antibodies for the detection of VEEV after a potential bioterrorism assault or an natural outbreak of VEEV.
\end{abstract}

Results: In this work, human anti-VEEV single chain Fragments variable (scFv) were isolated for the first time from a human naïve antibody gene library using optimized selection processes. In total eleven different scFvs were identified and their immunological specificity was assessed. The specific detection of the VEEV strains TC83, HI2/93 and 230 by the selected antibody fragments was proved. Active as well as formalin inactivated virus particles were recognized by the selected antibody fragments which could be also used for Western blot analysis of VEEV proteins and immunohistochemistry of VEEV infected cells. The anti-VEEV scFv phage clones did not show any cross-reactivity with Alphavirus species of the Western equine encephalitis virus (WEEV) and Eastern equine encephalitis virus (EEEV) antigenic complex, nor did they react with Chikungunya virus (CHIKV), if they were used as detection reagent.

Conclusion: For the first time, this study describes the selection of antibodies against a human pathogenic virus from a human naïve scFv antibody gene library using complete, active virus particles as antigen. The broad and sensitive applicability of scFv-presenting phage for the immunological detection and diagnosis of Alphavirus species was demonstrated. The selected antibody fragments will improve the fast identification of VEEV in case of a biological warfare or terroristic attack or a natural outbreak. 


\section{Background}

Venezuelan equine encephalitis virus (VEEV) belongs to the Alphavirus genus within the Togaviridae family and was first isolated from horses in the end of the 1930s $[1,2]$. These viruses have a natural transmission cycle between rodents and mosquitos [3]. Millions of horses were affected by this arbovirus with a fatality rate of up to $80 \%$ in epidemics in Central and South America [4].

Several species of this family are pathogenic to humans and are recognized as potential biological warfare agent (BWA) [5]. VEEV is classified as Bioterrorism Agent Category B by the center of Disease Control (CDC). Alphaviruses do not only have the potential for illness and transmission, but they can also be produced in large quantities and are moderately easy to disseminate. Furthermore, these virus species have the capacity to cause human epidemics [6-11]. VEEV causes disease symptoms ranging from mild febrile reactions to fatal encephalitic zoonoses. Outcomes are significantly worse for young and elderly patients, with case fatalities ranging from 4 to $35 \%$ $[12,13]$. These viruses are highly infectious as aerosols $[14,15]$ and an intentional release of sufficient quantities as inhalable small-particle aerosol is expected to infect a high percentage of individuals within an area of a least $10,000 \mathrm{~km}^{2}[16]$. They can replicate in cell culture to very high titers and are relatively stable to environmental influences [17].

For the surveillance of possible bioterrorism targets and endangered populations, rapid detection and diagnosis of VEEV are of crucial importance. In the past, the generation of monoclonal murine antibodies has improved the fast identification of VEEV infections to locate human and equine outbreaks of encephalitis. On the other hand, monospecific diagnostic monoclonal antibodies (mAbs) against VEEV are either hardly available on the market or too expensive for extensive use. In view of these current limitations the generation of specific high affinity recombinant antibodies may significantly improve the current situation and can make the rapid immunological detection widely available.

A promising method to generate recombinant antibodies against human pathogenic viruses like VEEV is the antibody phage display technology. Using antibody phage display, genotype and phenotype of an antibody fragment are linked by fusing the antibody gene fragment to the minor coat protein III gene of the filamentous bacteriophage M13. The resulting antibody fragment::pIII fusion protein is displayed on the surface of the phage particles [18-21]. The most common antibody formats used for this technology are the Fragment antigen binding (Fab) and the single chain Fragment variable (scFv). In comparison to the Fab, that is consisting of the Fragment deter- mining (Fd) of the heavy chain and the light chain linked by a disulphide bond, the scFv simply consists of the variable region of the heavy chain $\left(\mathrm{V}_{\mathrm{H}}\right)$ and the variable region of the light chain $\left(\mathrm{V}_{\mathrm{L}}\right)$, connected by a short peptide linker $[22,23]$. The selection of antibody fragments from antibody gene libraries is performed by an in vitro selection process $[24,25]$, that is also referred to as "panning".

In this study, we demonstrated the selection of human antibody fragments from a naïve antibody gene library specific for the detection of VEEV. We describe their immunological properties and discuss their possible application of these antibodies for diagnosis and detection of VEEV after a potential bioterrorism assault or natural outbreak of VEEV.

\section{Results \\ Selection of recombinant antibodies against VEEV from a human naïve antibody library}

In order to generate antibody fragments reactive to members of the VEE virus serocomplex the human naive scFv antibody gene library HAL4/7 was used. All pannings were performed in a biosafety level 3 laboratory and the vaccine strain, TC83, as a medically important and epizootic Alphavirus species was used as antigen.

The phage library was subjected to 3 rounds of panning and representative phage clones were assessed for their ability to bind VEEV TC83 immobilized onto 96 microwell plates. In order to exclude the enrichment of false-positive phage, the binding to supernatant of non-infected Vero cells (VRS concentrated and unconcentrated) was determined. Furthermore, the non-specific bindings of $\mathrm{scFv}$ phage to the VEEV-specific capture antibodies $\mathrm{mAb}$ 8747 and mAb VEE-WIS without and with an non-specific antigen, like lysozyme, was examined. As shown in figure 1 a significant enrichment of VEEV-specific polyclonal antibody phage occurred after the third panning round. However, besides the specific accumulation of binders also a severe co-enrichment of antibodies to the capture antibodies was observed.

Single clones were isolated from the third panning round. Soluble scFvs were produced in microtitre plates and analyzed by antigen ELISA on immobilized inactivated VEEV particles. The ELISA analysis using soluble scFvs instead of $\mathrm{scFv}$ phage minimized the occurance of false positives, because some antibody fragments bind only as antibody phage particles. Inactivated VEEV particles were used to ensure that the antibodies selected on active VEEV particles bound inactivated virus, too. In initial tests, we observed the enrichment of antibodies binding to Vero cell culture components. This effect was enhanced if VEEV particles were directly coated onto the wells and not cap- 


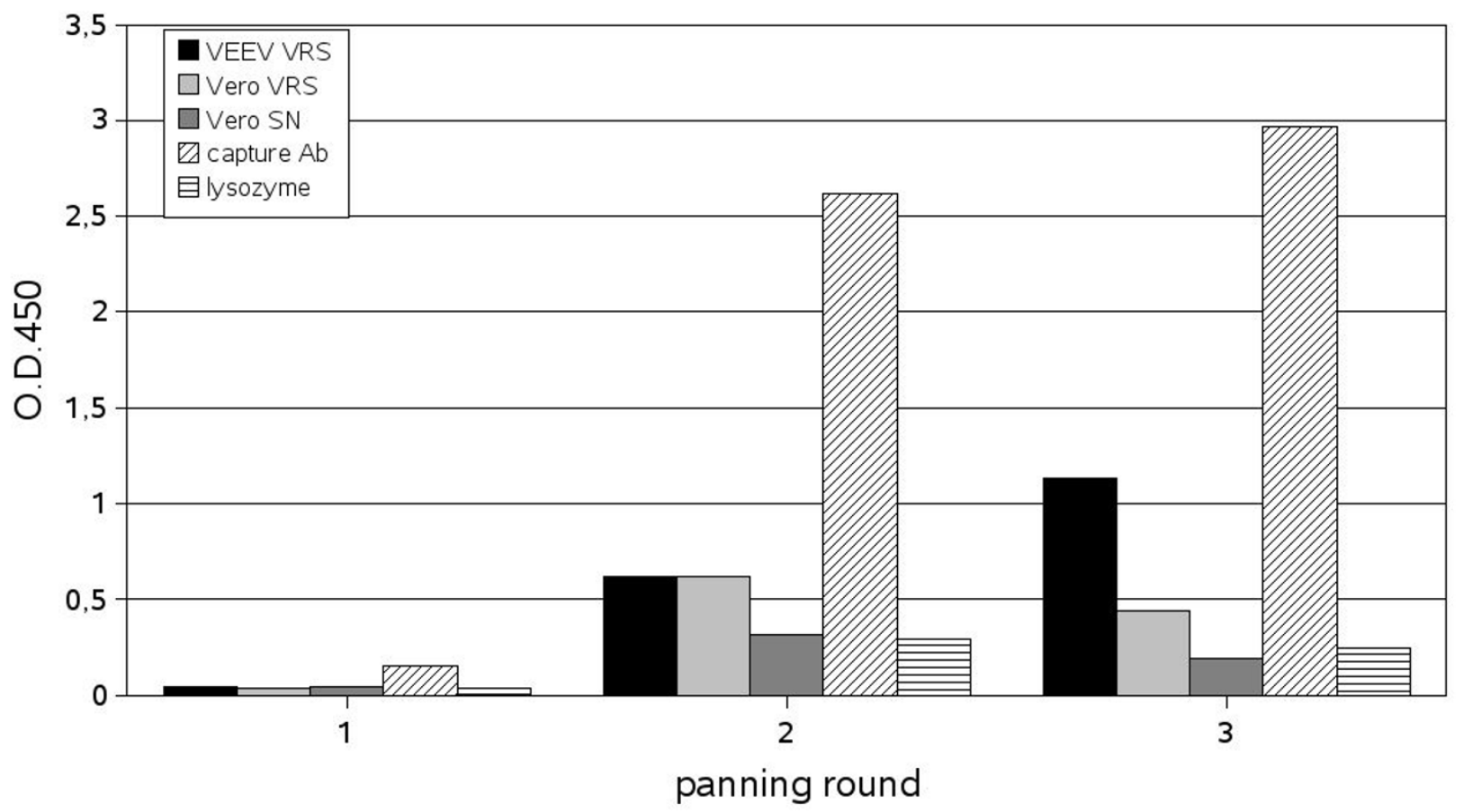

Figure I

ELISA with $10^{10}(\mathrm{cfu})$ polyclonal scFv phage of each panning round. Antigen (directly immobilized): I $\mu g$ VRS purified VEEV particles (VEEV VRS), I $\mu$ g VRS concentrated supernatant from non-infected Vero cells (Vero VRS), I:2 diluted supernatant of non infected VERO cells (Vero SN), $0.5 \mu \mathrm{g}$ of each anti-VEEV capture mAb 8747 and VEE-WISI, I $\mu g$ lysozyme. The bound scFv phage were detected using $\mathrm{mAb}$ anti-MI 3 conjugated with HRP (I:5000).

Table I: Anti-VEEV scFvs

\begin{tabular}{|c|c|c|c|c|c|}
\hline \multirow[t]{2}{*}{ scFv clone } & \multicolumn{3}{|c|}{$\mathrm{VH}$} & \multicolumn{2}{|c|}{ VL } \\
\hline & HV & $\mathrm{D}$ & $\mathrm{HJ}$ & LV & LJ \\
\hline CHN24-2-AI & IGHVI-69*0I & IGHD2-8*02 & IGHJ5*02 & IGLV3-I*0I & IGLJ3*0I \\
\hline $\mathrm{CHN} 24-2-\mathrm{A} 2$ & IGHV3-9*0I & IGHD6-19*0I & IGHJ3*02 & IGLV3-I*0I & $|G L J| * 0 \mid$ \\
\hline CHN24-2-B7 & IGHVI-I8*0I & IGHD2-2I*02 & IGHJ3*02 & IGLV2-I4*04 & IGLJ3*0I \\
\hline $\mathrm{CHN} 24-2-\mathrm{C} 2$ & IGHVI-69*0I & IGHD6- $|3 * 0|$ & IGHJ3*02 & IGLV3-2I*0| & IGLJ3*0 I \\
\hline CHN24-2-C3 & IGHV3-23*0I & IGHD6-I3*0| & IGHJ6*03 & IGLV3-I*0I & IGLJI*0I \\
\hline CHN24-2-D5 & IGHVI-8*0| & IGHD6-6*0 linv & IGHJ6*02 & IGLV2-I4*04 & IGLJ3*02 \\
\hline CHN24-2-FII & IGHVI-I8*0I & IGHD6-6*0I & IGHJ4*02 & IGLV6 & IGLJ3*02 \\
\hline MK269-CIO & IGHV3-30*04 & IGHD5-5*0I & IGHJ6*02 & IGLV2-I4*02 & IGLJI*0I \\
\hline MK269-EII & IGHV4-34*0 I & IGHD3-3*0I & IGHJ4*02 & IGLVI-5I*02 & IGLJ3*0I \\
\hline MK269-EI2 & IGHV4-4*02 & IGHD2-2I*0 I inv & IGHJ5*02 & IGLV3-2I*02 & IGLJ3*0I \\
\hline MK27I-G2 & IGHVI-69*0I & IGHD3-16*0I & IGHJ6*02 & IGLV3-2I*02 & IGLJ3*02 \\
\hline
\end{tabular}

Tab. I. Given are the names of the gene segments according to VBASE2. Abbreviations: HV: V (variable) gene segments of the heavy chain; D: D (diversity) gene segment; HJ: J (joining) gene segment of the heavy chain; LV: $\vee$ gene segment of the light chain; LJ: J gene segment of the light chain. 
tured by antibodies. Therefore, VRS purified Vero cell culture supernatant from non virus infected cells was used, because proteins from the cell culture supernatant were also enriched by the VRS system. In total, 230 antibody clones were analyzed by antigen ELISA (data not shown). Due to the signal to noise ratio, 26 VEEV binding $\mathrm{scFv}$ clones were further subjected to BstNI fingerprinting to sort out clones with identical restriction pattern (data not shown). After DNA sequencing, 10 different scFvs were finally found from this panning (designated with CHN24$\mathrm{x}$ and MK269-x). One additional scFv clone (MK271-G2) was isolated by a slightly different panning strategy. Interestingly, only antibodies with lambda light chains were obtained. According to the integrative database of germline variable genes from the immunoglobulin loci of human (VBASE2) the isolated scFv fragments contained the antigen-binding variable domains of the light chains LV1, 2, 3 and 6. The heavy chains of the isolated scFvs belonged to the subfamily HV1, 3 and 4, while HV1 predominated (table 1).

\section{Production and characterization of VEEV-specific scFv phage}

In order to prove the presentation of functional scFvs on the selected monoclonal $s c F v$ phage clones, the clones were subjected to immunoblot analysis. ScFv phage were separated by SDS-PAGE under reducing conditions and the corresponding immunoblot was stained using an antipIII mAb. All scFv phage preparations showed a nearly equal and efficient display of $\mathrm{scFv}$ antibodies on their surface. This straightly allows to compare the cognate ELISA, Western blot and immunohistochemistry results. The
anti-pIII immunoblot of a selection of anti-VEEV scFv phage is shown in figure 2.

\section{Verification of the VEEV-specific immunoreaction with scFv phage and scFv-Fc fusions}

In order to evaluate whether the antibody format or design influences the specific binding capacity, ELISA results obtained with selected $s c F v$ phage (figure $3 \mathrm{~A}$ ) and their corresponding scFv-Fc fusions (figure $3 \mathrm{~B}$ ) were compared. Purified formalin inactivated VEEV TC83 antigen was immobilized onto microwells and serial dilutions of either anti-VEEV scFv phage or serial dilution of $\mathrm{scFv}-\mathrm{Fc}$ fusion proteins were used for detection. All selected $\mathrm{scFv}$ phage clones and the corresponding scFv-Fc fusions were able to bind directly immobilized VEEV particles (figure 3 ). The background binding of the control antibody IIB6 scFv phage increased when using very high $s c F v$ phage particle concentrations. A scFv phage concentration of about $1 \times 10^{9}-5 \times 10^{9} \mathrm{scFv}$ phage particles, respectively $10-100$ $\mathrm{ng} / \mathrm{mL} \mathrm{scFv}-\mathrm{Fc}$ fusion proteins are well suited for the detection of immobilized VEEV particles. Additionally, it was also possible to detect direct immobilised active VEEV TC83 particles by ELISA using scFv phage (figure 4A), respectively $\mathrm{scFv}-\mathrm{Fc}$ fusion proteins (figure $4 \mathrm{~B}$ ).

SDS-PAGE and Western blotting are valuable approaches to examine which VEEV structural proteins are recognized by the selected anti-VEEV antibody fragments. Since the viral glycoproteins E1 and E2 can be separated from each other under non-reducing conditions, virus samples were first disintegrated by incubation for 20 minutes at $56^{\circ} \mathrm{C}$ in Laemmli sample buffer containing no 2-mercaptoetha-

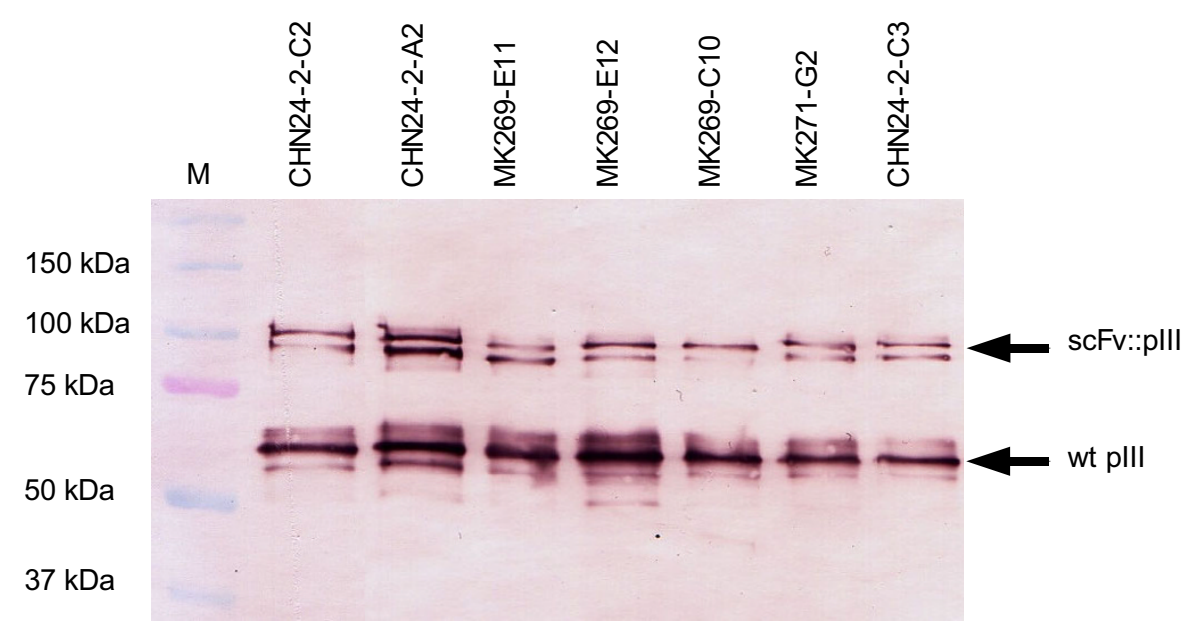

Figure 2

Immunoblot of anti-VEEV scFv phage. I $\times 10^{\prime \prime}(\mathrm{cfu}) \mathrm{scFv}$ phage per lane were separated on a reducing I0\% SDS-PAGE, followed by Western blot and detection of wildtype plll or scFv::pll fusion using mouse mAb anti-pllI (I:2000) and goat antimouse HRP ( $1: 5000)$. A selection of seven anti-VEEV scFv phage clones is shown. 
A

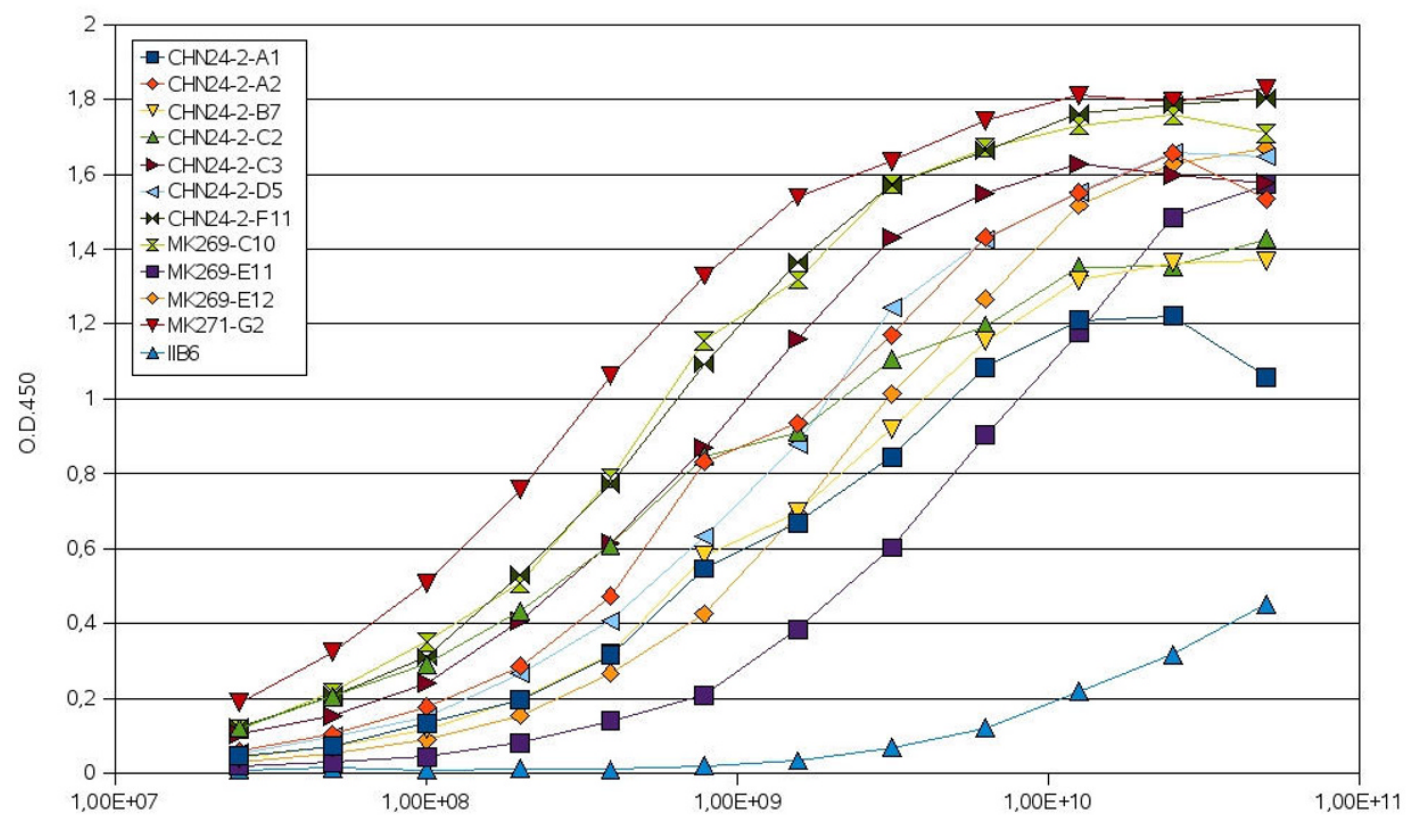

scFv phage particles [cfu/mL]

B

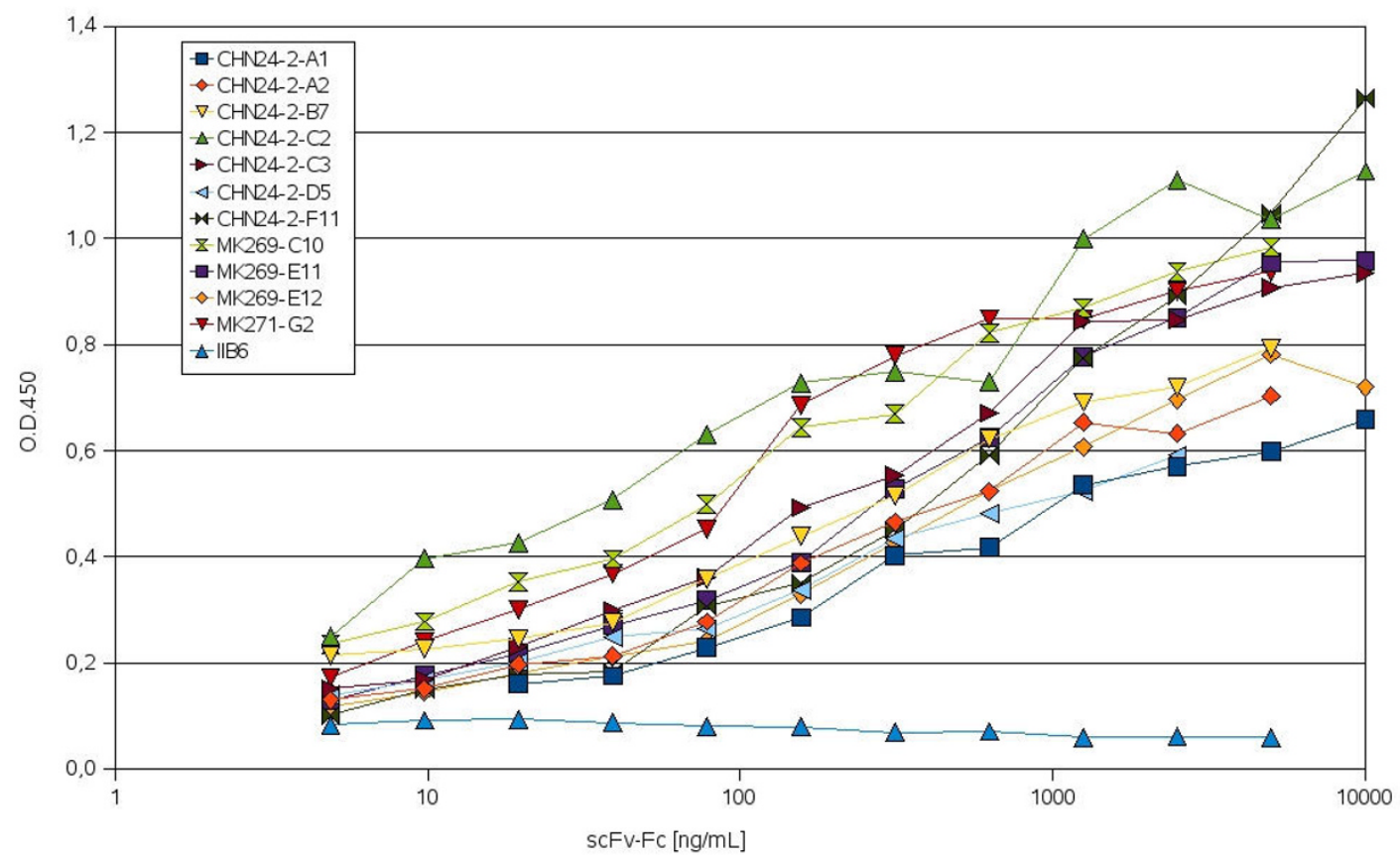

\section{Figure 3}

ELISA on directly immobilized inactive VEEV particles. Antigen: I $\mu \mathrm{g}$ VRS purified VEEV particles. A. A dilutions series of scFv phage particles were used for VEEV detection. The scFv phage were detected using mAb anti-MI 3 conjugated with HRP ( I:5000). The mean values of two ELISAs from two independent scFv phage productions are shown. B. A series of scFv-Fc fusion protein dilutions were used for VEEV detection. The scFv-Fc were detected using goat anti-human IgG Fc specific antibody conjugated with HRP (I:20000). IIB6 is a non VEEV-specific control scFv antibody. 
A

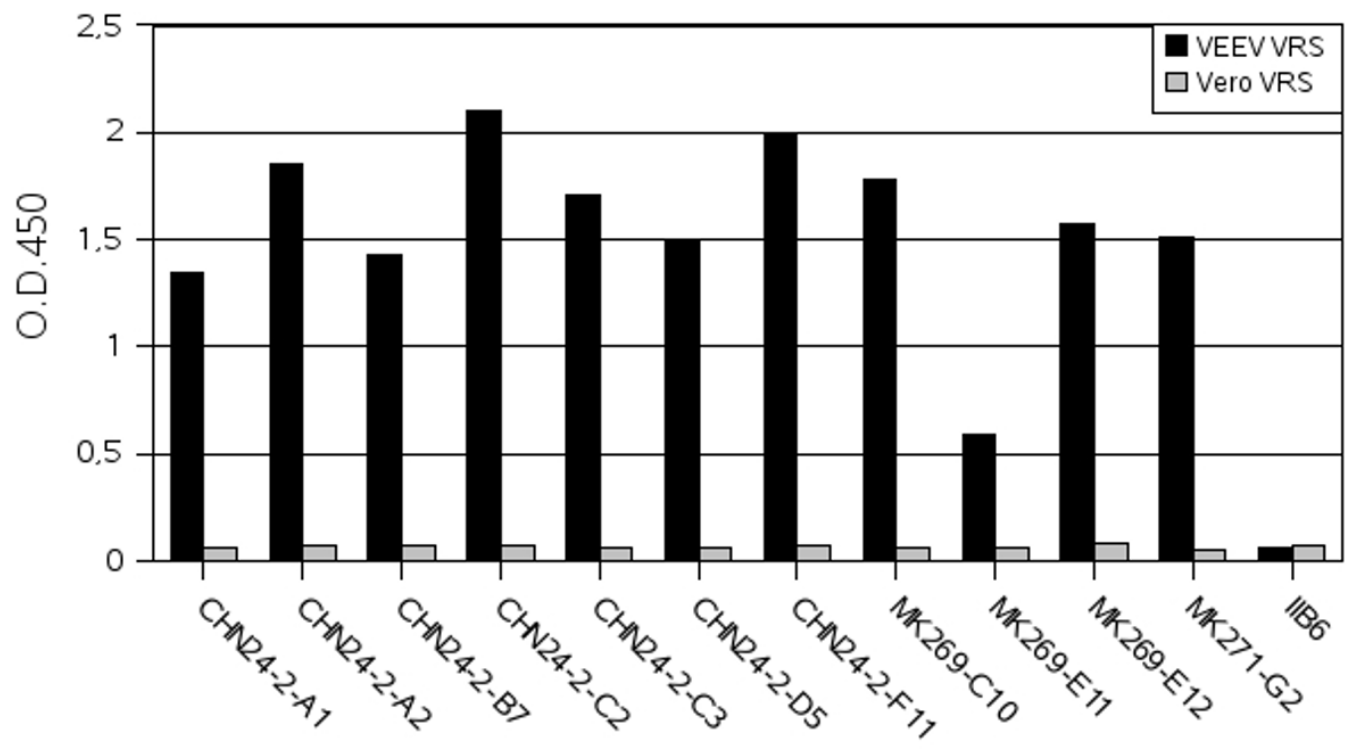

anti-VEEV scFV phage clone

B

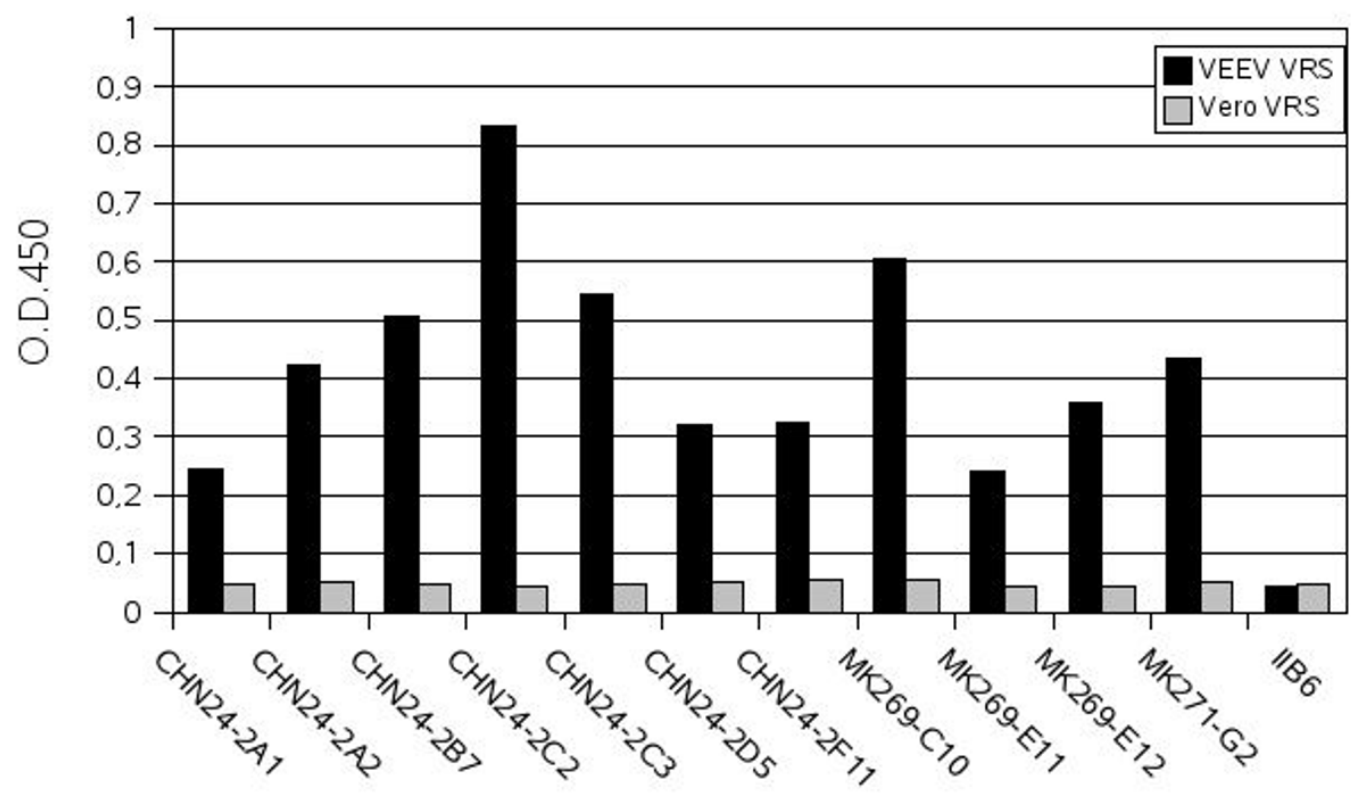

anti-VEEV scFV-Fc clone

\section{Figure 4}

ELISA on directly immobilized active VEEV particles. Antigen: I $\mu g$ VRS purified VEEV particles or I $\mu \mathrm{g}$ VRS concentrated supernatant from non-infected Vero cells as control. A. I × $10^{9} \mathrm{scFv}$ phage per well were used for VEEV detection. The scFv phage were detected as described in figure 3. The mean values of two ELISAs from two independent scFv phage productions are shown. B. $10 \mathrm{ng}$ per well $(100 \mathrm{ng} / \mathrm{mL}) \mathrm{scFv}-\mathrm{Fc}$ were used for VEEV detection. The scFv-Fc were detected as described in figure 3. 
nol. The samples were separated by $10 \%$ SDS-PAGE, blotted onto a PVDF membrane and stained as described. In general $5 \times 10^{10}$ anti-VEEV scFv phage/mL were used for the specific detection of structural proteins (Fig. 3A). The E2 protein specific antibodies mAb 8747 (Chemicon, CA, USA) and mAb 8/6 (Greiser-Wilke et al., 1989) served as positive control and displayed the expected electrophoretic profile typical for the Alphavirus E2 protein $(46,9 \mathrm{kDa})$ and the cognate viral E1/E2 heterodimer $(94,8$ $\mathrm{kDa}$ ). Interestingly, under non reducing conditions most of the anti-VEEV scFv phage displayed a nearly similar binding pattern and were able to bind either the E1 or E2 glycoprotein and the corresponding heterodimer (figure $5 \mathrm{~A})$. However, several of the specific scFv phage also caused an undefined smear if used in immunoblot analysis. This might be explained by prolonged staining. If the corresponding scFv-Fc fusions were used for binding, clear and defined bands, representing either E1 or E2 protein, were detectable similar to the $\mathrm{E} 2$ glycoprotein positive controls in figure 5B. In contrast, if virus samples were either prepared under reducing conditions or boiled prior to SDS-PAGE, no specific binding was observed. Therefore, the epitopes recognized by the scFv phage and scFvFc fusions are likely to be conformation dependent and the secondary structure seems to be critical for the binding of viral structural proteins. None of the isolated scFv fragments identified any linear epitopes.

\section{Evaluation of the cross-reactivity with different Alphavirus species and subspecies}

In order to test the cross-reactivity of the selected antibody clones with other strains of the VEEV as well as with other antigenic complexes, their binding was evaluated in a sandwich antigen catch ELISA by using an Alphavirus specific $\mathrm{mAb}$ mixture for capturing and the selected $\mathrm{scFv}$ phage for detection.

An established VEEV-specific (figure 6A) and Alphavirus genus-specific sandwich ELISA (figure 6B) served as positive control. As negative control, cell culture of noninfected Vero cells was used. As marker antibody the biotinylated anti-VEEV mAb 8/6 was used for the detection of all VEEV strains (figure 6A) and a biotinylated mixture of antibodies consisting of $\mathrm{mAb} 8 / 6, \mathrm{mAb}$ VEE-WIS1, mAb $12 / 2$ and $\mathrm{mAb} 42 / 2$ was used for the group specific detection of Alphaviruses (figure 4B). All viral antigens were captured by either the VEEV-specific mAb VEEV-WIS1 or a $\mathrm{mAb}$ mixture of anti-Alphavirus antibodies, consisting of mAb 3/4, mAb 12/2 and mAb VEE-WIS1 (WIS, Munster, Germany). Some virus strains (VEE-230) were captured better than others (VEE-H12/93).

All VEEV antigens were employed with a nearly similar $\mathrm{TCID}_{50} / \mathrm{mL}$ of $3 \times 10^{8}$ to $1 \times 10^{9}$. In addition to the VEEV vaccine strain TC83 of subtype IAB, the USSR (Russian) vaccine strain VEEV 230 and the British NCPV strain VEEV $12 / 93$ were applied. Furthermore, the selected $\mathrm{scFv}$ clones were tested for the specific detection of Eastern equine encephalitis virus (EEEV) strain H178/99, Western equine encephalitis virus (WEEV) strain H160/99 and Chikungunya virus (CHIKV) strain S27 Petersfield.

Positive ELISA signals were obtained for the different VEEV strains with all tested scFv phage clones (figure 6C). In contrast, the $\mathrm{scFv} \mathrm{CHN}-24-2 \mathrm{~A} 1$ showed a comparable low antigen binding. Maximum binding in the antigen sandwich ELISA was found for the Russian strain VEEV 230. This might be explained by the fact that this virus sample was chemically inactivated prior to use. We suppose that dependent on the inactivation the critical epitopes are more accessible for antibody detection.

However, none of the selected anti-VEEV scFv phage showed any cross-reactivity with other Alphaviruses, when used as detection antibody. All positive controls exhibited the expected binding pattern and were captured and detected by their specific mAbs in the ELISA.

\section{Detection of VEEV antigen in lysates of infected Vero cells} In order to examine the broad immunological applicability of the selected scFvs, we also tested the recombinant antibody fragments for the specific detection of VEEV TC83 in lysates of infected Vero cells. These cell lysates were prepared by disrupting infected cells with $4 \mathrm{M}$ urea while coupled to microwells. Detection was performed with $\mathrm{scFv}$ phage followed by an incubation with $\mathrm{mAb}$ anti-M13 conjugated to HRP. Lysates of non-infected Vero cells and VEEV antigen incubated with the mAb II-B6 served as negative control.

Specific binding could be confirmed for nearly all selected antibody fragments except for the clones CHN24-2-A1 and MK269-E11. The most stringent binding results were obtained with the scFv clones CHN24-2-A2, CHN24-2C3, CHN24-2-F11 and MK271-G2 (Fig. 7).

In addition, detection of VEEV-specific antigen by immunohistochemistry in TC83 infected and formaldehyde fixed Vero cells was possible. Similar to the results described above, all scFv clones, except for clone CHN242-A1, showed a specific cytoplasmic immunostaining of VEEV infected Vero cells (data not shown).

\section{Discussion}

For the detection of VEEV after an potential bioterrorims assault, e.g. by use of a VEEV aerosol, or a natural outbreak of VEEV, a fast diagnosis of these pathogen is necessary. The present work describes for the first time the screening and isolation of anti-VEEV antibody fragments from a human naïve antibody gene library by phage display. Ten 
A

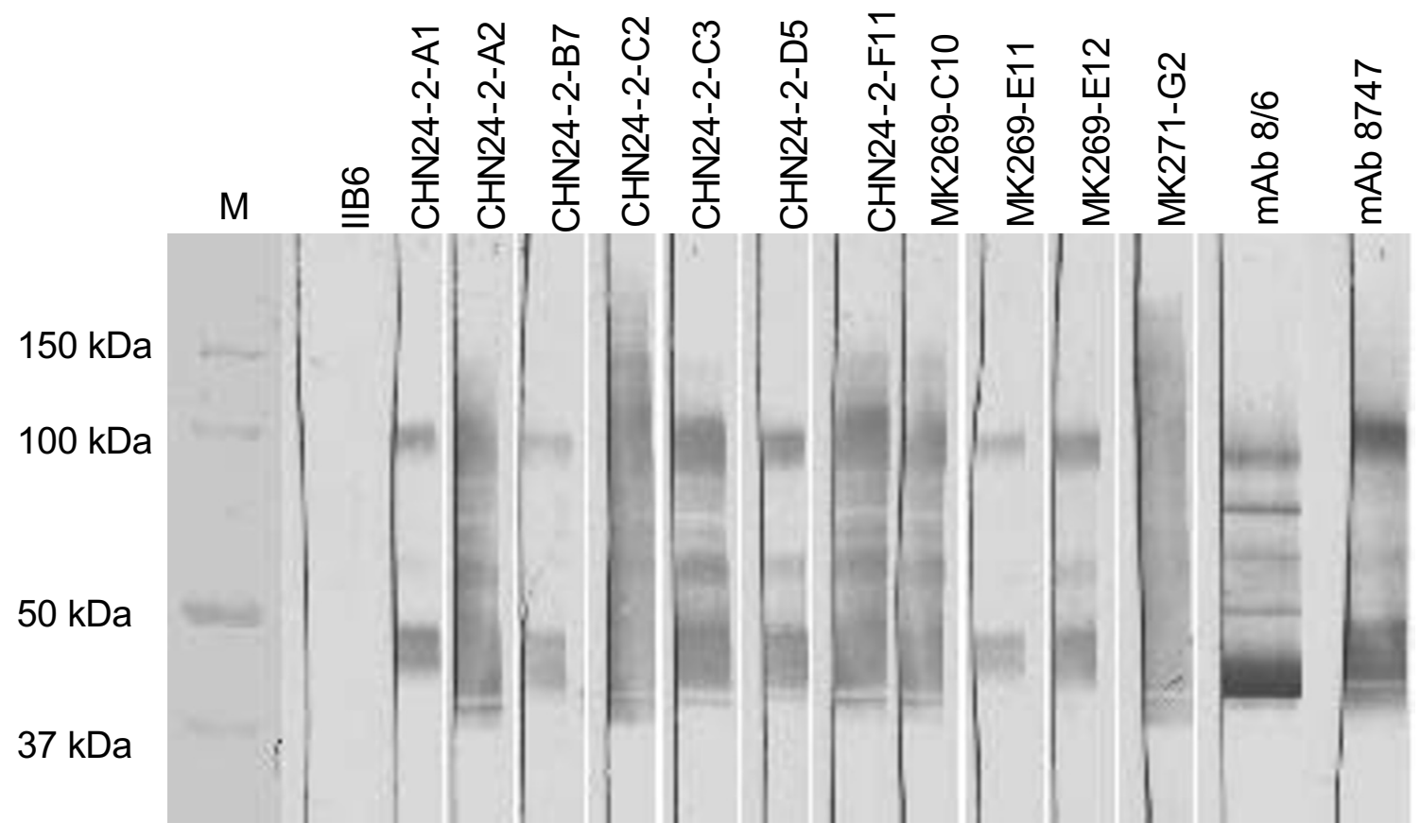

B

\section{CHN24-2-C2 MK269-C10 IIB6 mAb 8/6 mAb 8747 $56^{\circ} \mathrm{C} \quad 99^{\circ} \mathrm{C} \quad 99^{\circ} \mathrm{C} 56^{\circ} \mathrm{C} 99^{\circ} \mathrm{C} \quad 56^{\circ} \mathrm{C} \quad 56^{\circ} \mathrm{C} 56^{\circ} \mathrm{C}$}

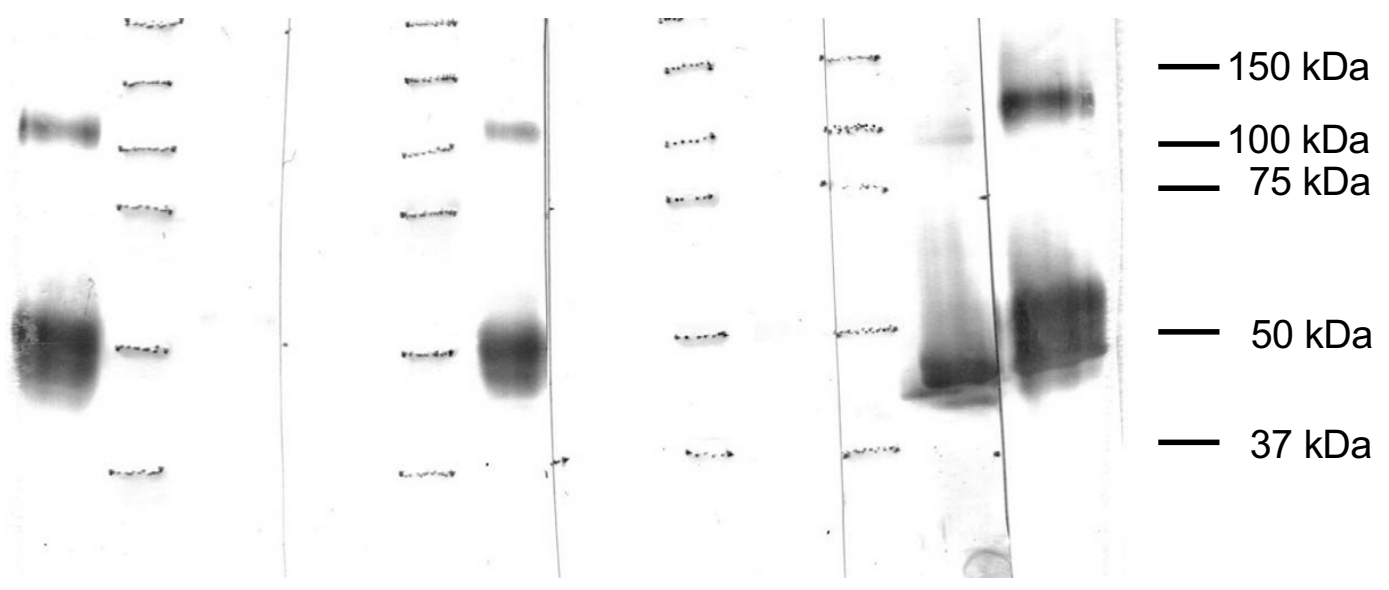

\section{Figure 5}

Immunoblot analysis of VEEV antigen detected by scFv phage or scFv-Fc fusions. VEEV VRS preparations were prepared at $56^{\circ} \mathrm{C}$ under non-reducing conditions and separated by $10 \%$ SDS-PAGE. After Western blot membranes were cut in stripes corresponding to 5-6 $\mu \mathrm{g}$ VEEV proteins. A. Immunostain was performed with $5 \times 10^{10}$ (cfu) anti-VEEV scFv phage particles/mL, murine anti-VEEV mAbs $8 / 6$ and $8747(\mathrm{I}: 1000)$ and detected with mAb mouse anti-MI3 HRP (I:4000), respectively goat antimouse IgG Fc specific HRP (I:I0000). IIB6 is a non VEEV-specific control scFv phage. B. Additionally, VEEV VRS samples were prepared at $56^{\circ} \mathrm{C}$ under non-reducing or at $99^{\circ} \mathrm{C}$ under reducing conditions, respectively. Western blots were stained with I $\mu \mathrm{g} / \mathrm{mL}$ scFv-Fc and murine anti-VEEV IgG (I:I000) and detected with goat anti-human (gamma chain specific) AP (I:5000), or goat-anti mouse (Fc specific) AP (I:10000), respectively. The marker bands were marked with a pencil. 
A

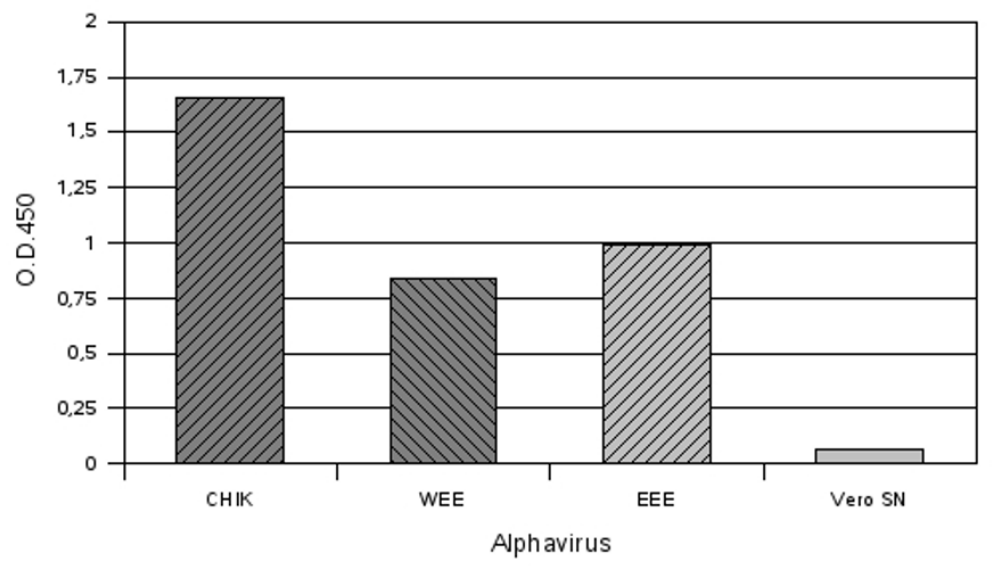

B

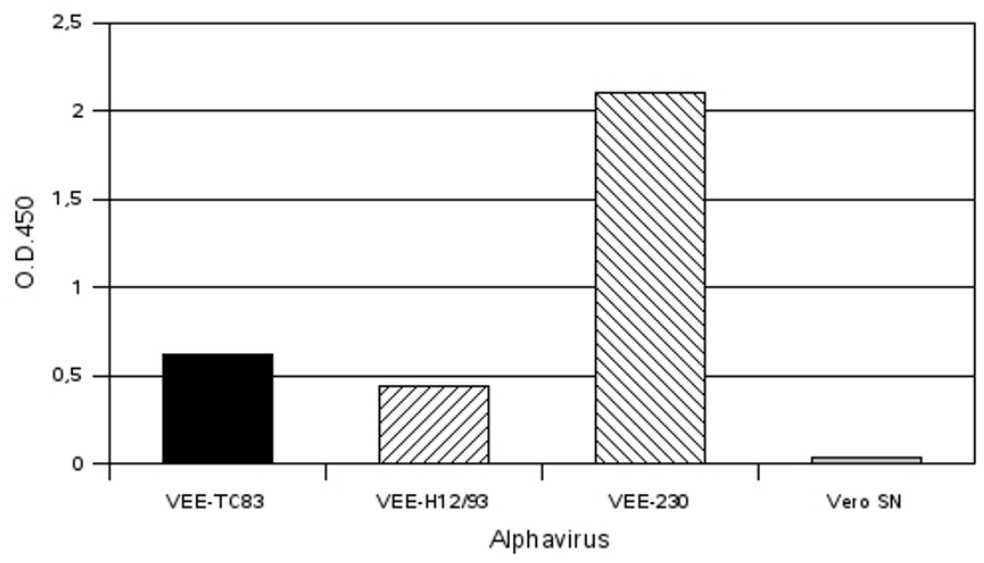

C

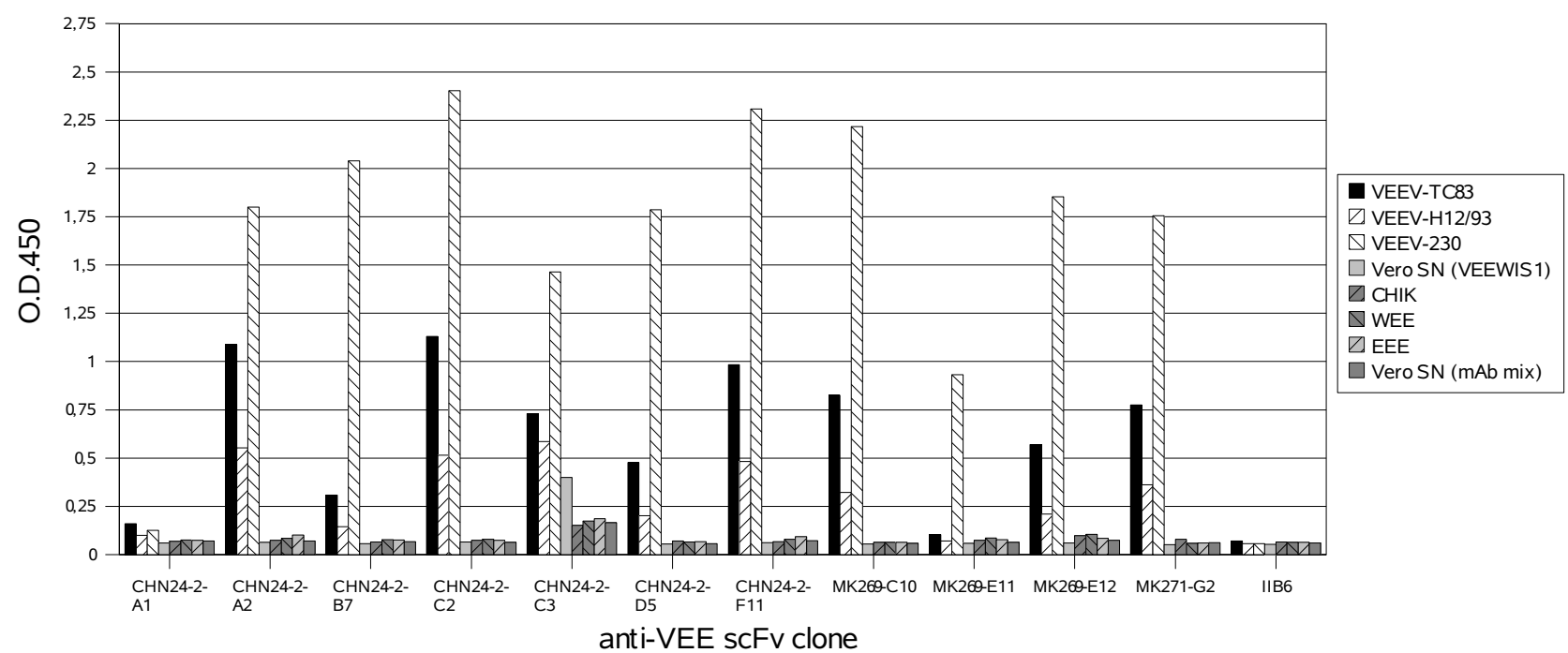

Figure 6 


\section{Figure 6}

Cross-reactivity of the anti-VEEV scFv clones and different anti-Alphavirus specific mAbs analyzed by ELISA. Antigens: VEEV strains TC83, 230 and HI2/93 were captured by using anti-VEEV mAb VEE-WISI $(3 \mu \mathrm{g} / \mathrm{mL})$; Eastern equine encephalitis virus (EEE), Western equine encephalitis virus (WEE) and Chikungunya (CHIK) were captured by using an anti-Alphavirus $\mathrm{mAb}$ mix consisting of mAb 3/4, mAb I2/2 and mAb VEE-WISI $(3 \mu \mathrm{g} / \mathrm{mL})$; Culture supernatant of non-infected Vero cells was captured once by anti-VEEV mAb VEE-WISI (VERO VEEWISI) or by a mAb mix consisting of mAb 3/4, mAb I2/2 and mAb VEE-WISI (VERO mAb mix). A. Staining with biotinylated anti-VEEV mAb 8/6 (I:10000) and streptavidin conjugated with HRP (I:4000). B. Staining with a biotinylated mixture of antibodies consisting of mAb 8/6 (I:l0000), mAb VEE-WISI (I:I0000), mAb I2/2 ( I:5000) and mAb 42/2 (I:2000) followed by a streptavidin-HRP ( I:4000) incubation. C. Staining with I $\times 10^{9}(\mathrm{cfu}) \mathrm{scFv}$ phage per well was followed by an incubation with mAb anti-MI 3 conjugated with HRP (I:5000). The IIB6 scFv phage was used as negative control. The mean values of two ELISAs from two independent scFv phage productions are shown.

out of eleven scFv clones were selected by the panning strategy using a mAb mixture for virus capturing as described. One further clone, MK271-G2, was isolated by an alternative panning, that was performed on directly immobilized viral antigen. The use of antibody captured virus particles was the preferred panning strategy because preliminary tests revealed, that panning on directly immobilized VEEV antigen enhanced especially the enrichment of non-specific binders.
To our knowledge, there are no studies demonstrating the successful in vitro antibody selection against human pathogen complete virus particles using naïve antibody gene libraries. A successful panning against severe acute respiratory syndrome coronavirus using a human semisynthetic library is described by van den Brink et al. [26]. In most other studies recombinant or purified virus proteins were used for panning if using a naïve antibody gene library [27-29]. The pannings using complete particles are mostly performed using immune libraries, e.g de Carvalho et al. [30], Koch et al. [31] or Duan et al. [32]. The

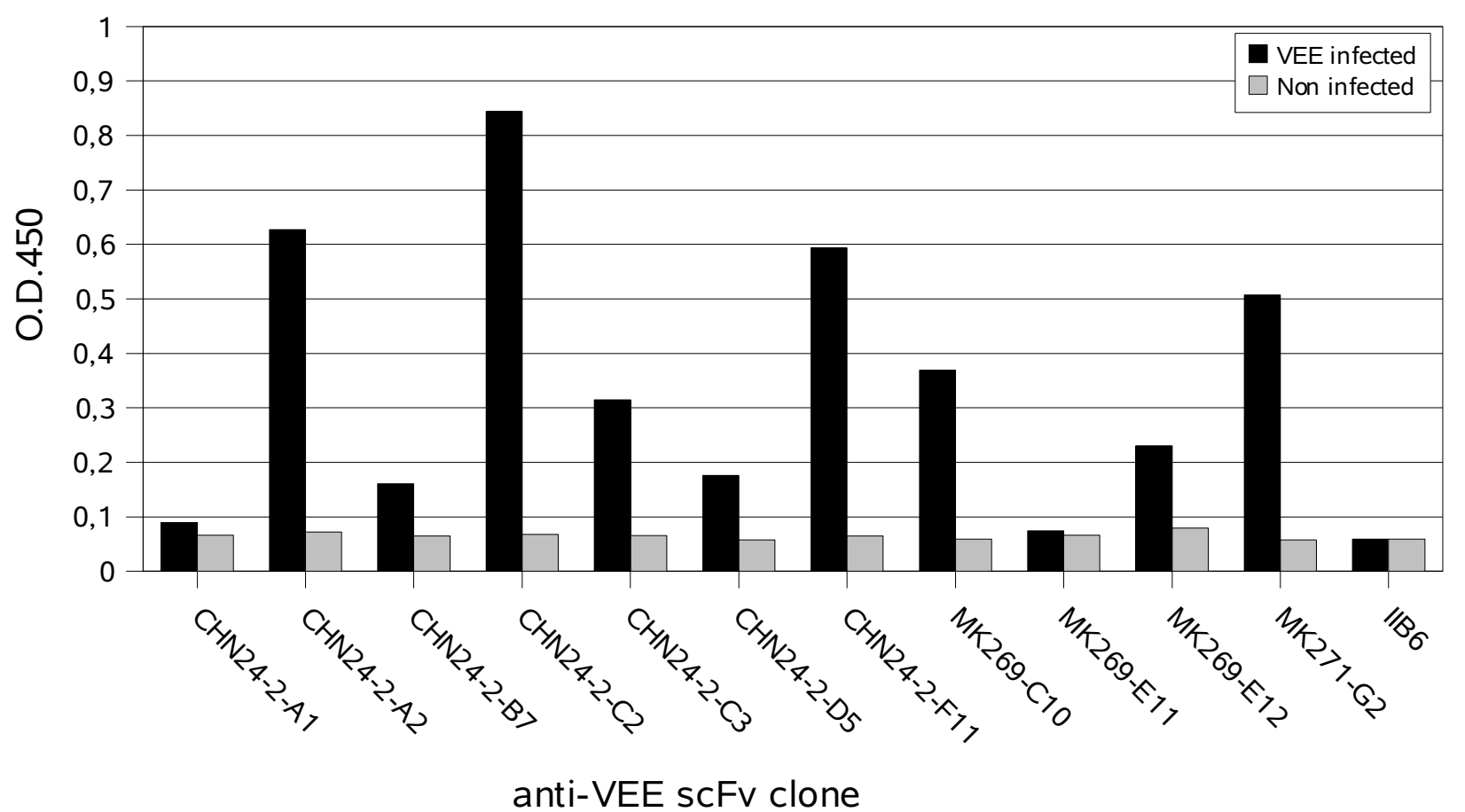

Figure 7

ELISA on VEEV infected cell lysate. Antigen: cell lysate from VEEV infected/non-infected Vero cells. VEEV was detected by using $\mathrm{I} \times 10^{9}$ (cfu) scFv phage per well followed by an incubation with mAb anti-MI 3 conjugated with HRP (I:5000). The IIB6 scFv phage was used as negative control. The mean values of two ELISAs from two independent scFv phage productions are shown. 
panning procedure described here might be also useful for the in vitro antibody selection of scFvs against other viral targets from human naïve antibody gene libraries, in particular when either immunized patients are not available or immunisation is not ethically feasible.

Nearly all scFvs were able to detect active as well as inactive VEEV TC83 viral antigen. Comparable indirect ELISA data were obtained with scFv phage and their corresponding scFv-Fc fusions. The specific immunoreaction could be verified by Western blot analysis, immunohistochemistry and by immunostaining of urea disrupted cell lysates. The selected antibody clones were reactive with all tested members of the VEE virus serocomplex but showed no significant cross-reactivity with closely related Alphavirus species like WEEV, EEEV and CHIKV, if used as detection molecules.

All Alphaviruses share a number of structural, sequential and functional similarities. Immunological typing approaches categorize the nearly 30 species into seven serocomplexes or species. The nucleotide and amino acid identity among these antigenic complexes, subtypes and varieties varies from 45 to $96 \%[2,3,33,34]$. In general, the sequences of structural proteins are more divergent than the sequences of non-structural proteins. In immunoblot analysis the anti-VEEV scFv phage displayed a similar binding pattern like the $\mathrm{E} 2$ protein specific antibodies mAb 8747 (Chemicon, CA, USA) and mAb 8/6 [35] and identified probably the $\mathrm{E} 2$ glycoprotein and the cognate viral E1/E2 heterodimer. Interestingly, all obtained scFv clones identified structural epitopes that are still folded after denaturation at $56^{\circ} \mathrm{C}$ under non-reducing conditions. In contrast, if the viral antigens were either prepared under reducing conditions or boiled prior to SDS-PAGE, no specific binding was observed.

A possible neutralisation activity of the selected scFvs has to be assessed in further studies. Normally, the protective immunity to Alphaviruses is associated with an antibody reactivity to the virion glycoproteins E2 and so far, six conformationally stable epitopes were identified as critical for virus neutralization [36-40]. Furthermore our antibodies are fully human and therefore better suited for applications like as passive vaccination than murine antibodies.

To date, VEEV diagnosis is performed using monoclonal and polyclonal antibodies [41] and also scFv fragments have been analysed [42]. This study showed that $\mathrm{scFv}$ phage are applicable for a broad range of anti-VEEV diagnosis assays: antigen ELISA on purified virus particles, ELISA on cell lysate and immunoblot. Furthermore, the recombinant fragments offer the possibility to develop a VEEV-specific diagnosis assay since the specific scFv phage can be easily produced and purified in high amounts. This could be an alternative to fullsize IgGs for an ELISA assay. At least, they might be applied for immuno-PCR [43] in order to increase the sensitivity of detection. These methods can be used for the diagnosis of VEEV in the enviroment and for the detection of human or equine VEEV infections.

\section{Conclusion}

For the first time, this study describes the selection of antibodies against a human pathogenic virus from a human naïve $\mathrm{scFv}$ antibody gene library using complete, active virus particles as antigen. The described antibody selection procedure may also be useful for the in vitro antibody selection of antibody fragments against other viral targets from human naïve antibody gene libraries, in particular when immunized patients are not available or immunisation is not ethically feasible. The broad and sensitive applicability of anti-VEEV scFv-presenting phage for the immunological detection and diagnosis of Alphavirus species was demonstrated. The selected recombinant antibody fragments will improve the rapid and specific detection of VEEV infections after human and equine outbreaks of encephalitis, where an early and definite identification is of critical importance.

\section{Methods \\ Cell culture and virus production}

Alphaviruses were grown in Vero cells (VERO-B4, African green monkey kidney cells, DSMZ-ACC 33, Deutsche Sammlung von Mikroorganismen und Zellkulturen $\mathrm{GmbH}$, Braunschweig, Germany) in biosafety level 2 and 3 facilities according to standard procedures [35]. Virus titers were determined by the $50 \%$ tissue culture infective dose $\left(\mathrm{TCID}_{50} / \mathrm{mL}\right)$ method $[44,45]$. All viruses used in this study represent models for biowarfare agent relevant Alphavirus species and are either part of the strain collection of the Armed Forces Scientific Institute for Protection Technologies - NBC Protection (WIS) or were received from the National Collection of Pathogenic Viruses (NCPV), UK. The viruses used in this study were VEEV strain TC83 (variety 1AB), VEEV strain 12/93, Eastern equine encephalitis virus (EEEV) strain H178/99, Western equine encephalitis virus (WEEV) strain H160/99 and Chikungunya virus (CHIKV) strain S27. The strain TC83 was obtained from the Trinidad donkey strain by serial passages on guinea pig embryo heart cells in 1960 [46]. Additionally, VEEV strain 230 antigen (inactivated by $\beta$ propiolactone) was purchased from Senova GmbH (Jena, Germany). Strain VEEV 230 is the former USSR vaccine strain. Its history of production is not exactly known but it has been produced by serial passages of a virulent natural strain on chick embryos [47]. If not particularily indicated, active virus material was used throughout the study. Lysates of VEEV infected cells were prepared by incubation with $4 \mathrm{M}$ urea for $15 \mathrm{~min}$ at room temperature (RT). 


\section{Purification of Alphaviruses}

Virus containing supernatants from infected Vero cells were either purified by affinity chromatography on Matrex Cellufine Sulfate Medium ${ }^{\mathrm{TM}}$ (Virus Recovery System, VRS, Chisso America Inc., NY, USA) or by isopycnic density gradient centrifugation. Matrex Cellufine Sulfate Medium $^{\mathrm{TM}}$ (VRS) is a cellulose bead medium functionalized with a low concentration of sulfate esters that operates similar to a cation-exchange resin and has a high affinity to enveloped viruses. It selectively adsorbs complete virus particles as well as viral coats according to their charge. Briefly, $50 \mathrm{~mL}$ resin was equilibrated with adsorption buffer (0.01 M phosphate buffer, $\mathrm{pH} 7.5$ ). Up to 200 mL of virus containing prefiltered cell culture supernatant was loaded onto the column which then was washed twice with $0.01 \mathrm{M}$ phosphate buffer, $\mathrm{pH}$ 7.5. Elution of virus particles was performed with $1 \mathrm{M} \mathrm{NaCl}$.

Virus particles were pre-purified using ultracentrifugation through the sucrose cushion method (20\% sucrose cushion), which causes low mechanical stress and allows the concentration and collection of morphologically intact particles after centrifugation at $112,000 \times \mathrm{g}$ for 2 to 3 hours. The pellet was resuspended in 0.5 to $1 \mathrm{~mL}$ phosphate buffered saline (PBS; [48]) and further purified by isopycnic density gradient centrifugation (20 to $60 \%$ sucrose) for 18 hours at $217,500 \times \mathrm{g}$. The virus containing fraction was removed, stored at $-80^{\circ} \mathrm{C}$ until subjected to further analysis.

\section{Selection of recombinant antibodies}

The panning procedure based on protocols by Hust et al. [25] with numerous modifications in 96 well microtitre plates (Maxisorb, Nunc, Wiesbaden, Germany). The mAb 8747 (Chemicon, Temecula, USA; [42]) and mAb VEEWIS1 (WIS, Munster, Germany) were incubated in concentrations of $1,5 \mu \mathrm{g} / \mathrm{mL}$ each overnight at $4^{\circ} \mathrm{C}$ in microtitre wells, followed by blocking with $1 \%(\mathrm{w} / \mathrm{v})$ BSA in PBST (phosphate buffered saline + 1\% Tween 20; [48]) for $1 \mathrm{~h}$ at RT. For every panning round one well was coated for the selection and one well was coated for a preselection step. For the preselection step $50 \mu \mathrm{L}$ VRS concentrated supernatant from non-infected Vero cells $+50 \mu \mathrm{L} 1 \%$ BSA in PBST was incubated. Afterwards, the wells were blocked with $2 \%$ skim milk powder in PBST. After $2 \mathrm{~h}$ at RT the wells were washed three times with PBST. In parallel, for selection, $50 \mu \mathrm{L}$ VRS purified VEEV $(2.7 \mathrm{mg} / \mathrm{mL})+50 \mu \mathrm{L}$ $1 \%$ BSA in PBST was captured for $1 \mathrm{~h}$ by gently shaking at RT, followed by overnight incubation at $4{ }^{\circ} \mathrm{C}$.

The human naïve HAL4/7 antibody gene library [49] consisting of in $5 \times 10^{9}$ independent clones in total based on the phagemid vector pHAL14 $[49,50]$ was used for panning. The library was packaged using Hyperphage [51-53]. Prior to panning $5 \times 10^{11} \mathrm{scFv}$ phage particles of HAL4 (kappa $\mathrm{V}_{\mathrm{L}}$ repertoire) and $5 \times 10^{11} \mathrm{scFv}$ phage particles of HAL7 (lambda $V_{L}$ repertoire) were mixed with $150 \mu \mathrm{L}$ „panningblock" solution (1\% (w/v) BSA $+1 \%(\mathrm{w} / \mathrm{v})$ skim milk in PBST). In the preselection step, the library phage suspension was incubated at RT for $2.5 \mathrm{~h}$ in the well with captured VRS concentrated supernatant from noninfected Vero cells to remove non-specific binders. The supernatant containing the depleted library was mixed with $1 / 10$ volume of VRS concentrated supernatant from non-infected Vero cells and $5 \mu \mathrm{g}$ of a non VEEV-specific murine IgG for competition. For the selection step, the library solution was incubated in the wells with the immobilised VEEV at RT for $2 \mathrm{~h}$ followed by 30 times washing with PBST. Afterwards the bound scFv phage particles were eluted with $200 \mu \mathrm{L}$ trypsin solution $(10 \mu \mathrm{g} / \mathrm{mL}$ trypsin in PBS) at $37^{\circ} \mathrm{C}$ for $30 \mathrm{~min}$. The supernatant containing the eluted $\mathrm{scFv}$ phage was transferred into a new tube. For the inactivation of the VEEV particles, $100 \mu \mathrm{L}$ of $0.1 \mathrm{M}$ glycin buffer pH 2.2 were added and incubated at RT for 15 min. The solution was neutralized with $100 \mu \mathrm{L}$ $0.1 \mathrm{M}$ phosphate buffer $\mathrm{pH}$ 7.6. $10 \mu \mathrm{L}$ of eluted $\mathrm{scFv}$ phage were used for titration as described by Hust et al. [25]. The remaining $\mathrm{scFv}$ phage were amplified as described by Hust et al. [25] and used for the next panning round. The second panning round using the amplified phage was performed with the following modifications: the amount of antigen was reduced by $50 \%$ and washing cycles during panning were increased to 60 . Additionally, in the third panning round the amount of antibody phage was reduced to $1 \times 10^{9} \mathrm{scFv}$ phage. Furthermore, cell culture supernatant from non-infected Vero cells, 1/10 volume, was used for competition.

\section{Antigen ELISA using scFv phage, scFvs and scFv-Fc fusions}

All ELISAs were performed in 96 microtitre well plates (Maxisorb $^{\mathrm{TM}}$, Nunc) that were coated with VRS purified viral antigen overnight at $4^{\circ} \mathrm{C}$. Afterwards the wells were washed three times with PBST and blocked with $2 \%(\mathrm{w} / \mathrm{v})$ skim milk powder in PBST (M-PBST) or with $1 \%$ fetal calf serum (FCS) in PBST for $1.5 \mathrm{~h}$ at RT, followed by three washes with PBST. ScFv phage, soluble antibody fragments or scFv-Fc fusion proteins were diluted in $100 \mu \mathrm{L}$ M-PBST and incubated with the antigen for $1.5 \mathrm{~h}$, followed by five washes with PBST. Bound scFv phage were detected by using the mAb anti-M13 conjugated with horseradish peroxidase (HRP) (GE Healthcare, München, Germany; 1:5.000). Bound soluble antibody fragments were detected by using the murine mAb 9E10 which recognizes the c-terminal c-myc tag. Staining was performed with a goat anti-mouse Ab conjugated to HRP (Sigma; $1: 10.000)$. The specific binding of $\mathrm{scFv}$-Fc fusion proteins to viral antigen was assessed with a goat anti-human Fc specific mAb conjugated to HRP (Sigma; 1:20.000), biotinylated mAbs were detected by using a Streptavidin HRP conjugate (GE Healthcare; 1:4.000). The visualization was 
performed with TMB (3,3',5,5'-tetramethylbenzidine) as substrate and the staining reaction was stopped by adding $100 \mu \mathrm{l} 1 \mathrm{M}$ sulphuric acid. Absorbance at $450 \mathrm{~nm}$ was measured by using a SUNRISE ${ }^{\mathrm{TM}}$ microtiter plate reader (Tecan, Crailsheim, Germany).

\section{Production of soluble antibody fragments in microtitre plate wells}

Microtitre plate wells containing $200 \mu \mathrm{L} 2 \mathrm{xTY}+100 \mathrm{mM}$ glucose $+100 \mu \mathrm{g} / \mathrm{mL}$ ampicillin (2xTY-GA) were inoculated with single E. coli colonies from the phage titration of the panning and incubated overnight at $37^{\circ} \mathrm{C}$ and with constant shaking at $1200 \mathrm{rpm} .200 \mu \mathrm{L} 2 \mathrm{xTY}$-GA was inoculated with $10 \mu \mathrm{L}$ of the overnight culture and grown at $37^{\circ} \mathrm{C}$ and $1200 \mathrm{rpm}$ for $2 \mathrm{~h}$. Bacteria were harvested by centrifugation for $10 \mathrm{~min}$ at $3220 \times \mathrm{g}$. The pellets were resuspended in $200 \mu \mathrm{l} 2 \mathrm{xTY}+100 \mu \mathrm{g} / \mathrm{mL}$ Ampicillin +50 $\mu \mathrm{M}$ isopropyl-beta-D-thiogalacto-pyranoside (IPTG), a substance that induces the prokaryotic lac $Z$ promotor in E. coli, and incubated at $30^{\circ} \mathrm{C}$ and $1200 \mathrm{rpm}$ overnight. Cells were removed from the scFv containing supernatant by centrifugation for $10 \mathrm{~min}$ at $3220 \times \mathrm{g}$ and $4{ }^{\circ} \mathrm{C}$.

\section{Sequencing}

Sequencing was performed using ABI Prism 310 Genetic Analyzer according to the manufacturers instructions using oligonucleotide primer MKpelB_f (5' GCCTACGGCAGCCGCTGG 3') or MKmyc_r (5' GATCCTCTTCTGAGATGAG 3'). The antibody gene fragments were analyzed by using VBASE2 http://www.vbase2.org[54,55].

\section{SDS-PAGE and immunoblot analysis}

In order to analyse the scFv presentation on phage, the SDS-PAGE (sodium dodecyl sulphate-polyacrylamid gel electrophoresis) of scFv phage followed by Western blot and immunostaining of PIII were performed as described by Kirsch et al. [56].

ScFv-Fc fusion proteins and scFv phage were used to detect VEEV proteins. VEEV particles were separated by SDSPAGE and blotted onto PVDF membrane. The membrane was blocked with M-PBST for $1 \mathrm{~h}$ at RT. ScFv phage or the scFv-Fc fusion protein were incubated for $1.5 \mathrm{~h}$ at RT, followed by two times washing with PBST. For the detection of bound scFv phage mAb mouse anti-M13 conjugated with HRP (GE Healthcare, 1:4000) was used for detection and visualized by $\mathrm{DAB}$ (diaminobenzidine). For the detection of the scFv-Fc fusion protein goat anti-human (Fc specific) conjugated with alcaline phosphatase (AP) (Dianova, Hamburg, Germany, 1:5000) was used. Murine IgGs were detected using goat anti-mouse (Fc specific) conjugated with AP (Sigma, 1:10000) and visualised by NBT/BCIP.

\section{Cloning and production of scFv-Fc fusion proteins}

VEEV-specific scFv gene fragments were subcloned from the library vector pHAL14 into the mammalian expression vector pCMV-hIgG1-Fc-XP (Schirrmann, manuscript in preparation) between the murine IgG signal peptide and the human IgG1 gene fragments by using the restriction sites NcoI and NotI. For the transient production of VEEV-specific scFv-Fc fusion proteins, the human embryonic kidney (HEK) cell line, 293T (American Type Culture Collection, ATCC, Rockwell, MD, No. CRL-11268) was transiently transfected by using the cell line specific lipid transfection reagent HEKfectin (Bio-Rad, München, Germany). $5 \times 10^{5}$ HEK293T cells were seeded and cultivated overnight into six well tissue culture plates (Sarstedt, Nürnbrecht, Germany) with $2 \mathrm{~mL}$ Dulbecco's Modified Eagle Medium (DMEM), supplemented with $2 \mathrm{mM} \mathrm{L}$ glutamine, $1.5 \mathrm{~g} / \mathrm{L}$ sodium bicarbonate and $4.5 \mathrm{~g} / \mathrm{L}$ glucose, $8 \%(\mathrm{v} / \mathrm{v})$ fetal calf serum (FCS) and $1 \%(\mathrm{w} / \mathrm{v})$ penicillin/streptomycin (PAA, Parsing, Austria) at $37^{\circ} \mathrm{C}$ in $7 \%$ $\mathrm{CO}_{2}$ atmosphere and at $95 \%$ humidity. For the transfection $2.5 \mu \mathrm{g}$ of plasmid DNA, encoding the scFv-Fc gene construct and $10 \mu \mathrm{L}$ HEKfectin were preincubated in DMEM before the DNA-liposome complexes were then added to the HEK cells. The cells were incubated overnight with the transfection mixture before the medium was exchanged to fresh one on the following day. After 72 hours culture supernatants containing the scFv-Fc fusion proteins were harvested. The scFv-Fc fusion protein content of the collected supernatants was analyzed using a human IgG capture ELISA as previously described [57].

\section{Authors' contributions}

MIK, BH performed the most experiments and helped to draft the manuscript. $\mathrm{CN}$ and TR performed some of the experiments. In addition, BH participated in the design and coordination of the study. TS and HJM particpated in the design and coordination of the study and helped to draft the manuscript. MH drafted the manuscript, participated in the design and coordination of the study and performed some of the experiments. SD conceived the project and wrote the grant application, particpated in the design and coordination of the study and helped to draft the manuscript. All authors read and approved the final manuscript.

\section{Acknowledgements}

We would like to thank Lars Toleikis for providing the mucin specific control antibody IIB6. We gratefully acknowledge the kind help of Svetlana Mollova, Ida Retter and Werner Müller for adapting VBASE2 to analysis of antibody $\mathrm{V}$-gene sequences directly derived from antibody selection projects. We would like to thank Luzie Voss and Saskia Helmsing for technical assistance. We would like to thank Steven R. Talbot for corrections and carefully reading the manuscript. We gratefully acknowledge the financial support by the German ministry of defense $(\mathrm{BMVg})$ and the financial support by the German ministry of education and research (BMBF, SMP "Antibody Factory" in the NGFN2 program). 


\section{References}

I. Kubes V, Rios FA: The causative agent of infectious equine encephalomytitis in Venezuela. Science 1939, 90(2323):20-21.

2. Powers AM, Brault AC, Shirako Y, Strauss EG, Kang W, Strauss JH, Weaver SC: Evolutionary Relationships and Systematics of the Alphaviruses. J Virol 2001, 75:101 I8-10131.

3. Strauss JH, Strauss EG: The alphaviruses: gene expression, replication, and evolution. Microbiol Rev |994, 58:49|-562.

4. Johnson KM, Martin DH: Venezuelan equine encephalitis. In Advances in the veterinary science and comparitive medicine Edited by: Brandley CA, Cornelius CE. New York and London: Academic Press; 1974:79-II6.

5. Hawley RJ, Eitzen EM: Biological weapons - a primer for microbioligist. Annu Rev Microbiol 200I, 55:235-253.

6. Powers AM, Oberste MS, Brault AC, Rico-Hesse R, Schmura SM, Smith JF, Kang W, Sweeney WP, Weaver SC: Repeated emergence of epidemic/epizootic Venezuelan equine encephalitis from a single genotype of enzootic subtype ID virus. J Virol 1997, 7 1:6697-6705.

7. Weaver SC, Salas R, Rico-Hesse R, Ludwig GV, Oberste MS, Boshell J, Tesh RB: Re-emergence of epidemic Venezuelan equine encephalomyelitis in South America. VEE Study Group. Lancet 1996, 348:436-440.

8. Sanchez JL, Takafuji ET, Lednar WM, LeDuc JW, Macasaet FF, Mangiafico JA, Rosato RR, Driggers DP, Haecker JC: Venezuelan equine encephalomyelitis: Report of an outbreak associated with jungle exposure. Mil Med 1984, I49:618-62I.

9. Sudia WD, Newhouse VF, Beadle ID, Miller DL, Johnston JG Jr, Young $\mathrm{R}$, Calisher $\mathrm{CH}$, Maness $\mathrm{K}$ : Epidemic Venezuelan equine encephalitis in North America in I97 I: vector studies. Am J Epidemiol 1975, I0 I: 17-35.

10. Franck P: Round table on epidemic control. In Venezuelan Encephalitis Volume 243. Pan American Health Organization. Washington DC; 1972:400-40I.

II. Rivas F, Diaz LA, Cardenas VM, Daza E, Bruzon L, Alcala A, De la Hoz O, Canceres FM, Aristizabal G, Martinez JW, Revelo D, De la Hoz F, Boshell J, Camacho T, Calderon L, Olano VA, Villareal LI, Roselli D, Alvarez G, Ludwig G, Tsai T: Epidemic Venezuelan equine encephalitis in La Guajira Colombia, 1995. J Infect Dis 1997, I 75(4):828-832.

12. Leitenberg M: Biological Weapons in the Twentieth Century: A Review and Analysis. Crit Rev Microbiol 200I, 27(4):267-320.

13. Hoke CH: History of U.S. Military Contributions to the Study of viral Encephalitis. Military Medicine 2005, I 70:92-I05.

14. Reed DS, Lind CM, Sullivan LJ, Pratt WD, Parker MD: Aerosol Infection of Cynomolgus Macaques with Enzootic Strains of Venezuelan Equine Encephalitis Viruses. J Infect Dis 2004, 189(6): $1013-1017$.

15. Johnstone RE, Peters C]: Alphaviruses. In Fields virology 3rd edition. Edited by: Fields BN, Knipe DM, Howley PM. Philadelphia, New York: Lippincott-Raven; 1995:843-898.

16. Smith JF, Davis K, Hart MK, Ludwig GV, McClain DJ, Parker MD, Pratt WD: Viral encephalitides. In Textbook of Military Medicine; Medical Aspects of Chemical and Biological Warfare Washington DC: Office of surgeon general; 1997:56 I-589.

17. Blue Book, Sixth Edition, April 2005. US Army Medical Research Institute of Infectious Disease (USAMRIID), Published by USAMRIID, the lead medical research laboratory for the US Biological Defense Research Program [http:// www.usamriid.army.mil/education/instruct.htm]

18. McCafferty J, Griffiths AD, Winter G, Chiswell DJ: Phage antibodies: filamentous phage displaying antibody variable domain. Nature 1990, 348:552-554.

19. Breitling F, Dübel S, Seehaus T, Kleewinghaus I, Little M: A surface expression vector for antibody screening. Gene I991, 104: 1047-153.

20. Clackson T, Hoogenboom HR, Griffiths AD, Winter G: Making antibody fragments using phage display libraries. Nature 1991, 352:624-628.

21. Hoogenboom HR, Griffiths AD, Johnson KS, Chiswell DJ, Hudson P, Winter G: Multi-subunit proteins on the surface of filamentous phage: methodologies for displaying antibody (Fab) heavy and light chains. Nucl Acids Res 1991, 19:4133-4137.

22. Better M, Chang CP, Robinson RR, Horwitz AH: Escherichia coli secretion of an active chimeric antibody fragment. Science |988, 240:104|-1043.
23. Huston JS, Levinson D, Mudgett HM, Tai MS, Novotny J, Margolies MN, Ridge RJ, Bruccoloreri RE, Haber E, Crea R, Oppermann H: Protein engineering of antibody binding sites: recovery of specific activity in an anti-digosin single-chain Fv analogue produced in Escherichia coli. Proc Natl Acad Sci USA 1988, 85:5879-5883.

24. Konthur Z, Hust M, Dübel S: Perspectives for systematic in vitro antibody generation. Gene 2005, 364:19-29.

25. Hust M, Dübel S, Schirrmann T: Selection of recombinant antibodies from antibody gene libraries. Methods Mol Biol 2007, 408:243-255.

26. Brink EN Van den, Ter Meulen J, Cox F, Jongeneelen MA, Thijsse A, Throsby M, Marissen WE, Rood PM, Bakker AB, Gelderblom HR, Martina BE, Osterhaus AD, Preiser W, Doerr HW, de Kruif J, Goudsmit J: Molecular and biological characterization of human monoclonal antibodies binding to the spike and nucleocapsid proteins of severe acute respiratory syndrome coronavirus. J Virol 2005, 79: I635-I644.

27. Rodriguez-Diaz J, Monedero V, Perez-Martinez G, Buesa J: Singlechain variable fragment (scFv) antibodies against rotavirus NSP4 enterotoxin generated by phage display. J Virol Methods 2004, I 2 I (2):23 I-238.

28. Donà MG, Giorgi $\mathrm{C}$, Accardi L: Characterization of antibodies in single-chain format against the $E 7$ oncoprotein of the human papillomavirus type 16 and their improvement by mutagenesis. BMC Cancer 2007, 7:25.

29. Velappan N, Martinez JS, Valero R, Chasteen L, Ponce L, BonduHawkins V, Kelly C, Pavlik P, Hjelle B, Bradbury AR: Selection and characterization of scFv antibodies against the Sin Nombre hantavirus nucleocapsid protein. J Immunol Methods 2007, 32 I ( I-2):60-69.

30. De Carvalho NC, Williamson RA, Parren PW, Lundkvist A, Burton DR, Bjöhrling E: Neutralizing human Fab fragments against measles virus recovered by phage display. J Virol 2002, 76:25I-258.

31. Koch J, Liang M, Queitsch I, Kraus AA, Bautz EKF: Human recombinant neutralizing antibodies against Hantaan virus $G 2$ protein. Virology 2003, 308:64-73.

32. Duan J, Ji X, Feng J, Han W, Zhang P, Cao W, Guo X, Qi C, Yang D, Jin G, Gao G, Yan X: A human neutralizing antibody against a conformational epitope shared by oligomeric SARS S I protein. Antivir Ther 2006, I I: I I7-123.

33. Calisher $\mathrm{CH}$, Karabatsos $\mathrm{N}$, Lazuick JS, Monath TP, Wolff KL: Reevaluation of the western equine encephalitis antigenic complex of alphaviruses(family Togaviridae) as determined by neutralization tests. Am J Trop Med Hyg 1988, 38:447-52.

34. Nagata LP, Hu WG, Parker M, Chau D, Rayner GA, Schmaltz FL, Wong JP: Infectivity variation and genetic diversity among strains of Western equine encephalitis virus. J Gen Virol 2006, 87:2353-236l.

35. Greiser-Wilke IM, Moennig M, Kaaden OR, Shope R: Detection of alphaviruses in a genus-specific antigen capture enzyme immunoassay using monoclonal antibodies. J Clin Microbiol |99|, 29:131-137.

36. Mathews JJ, Roehrig JT: Determination of the protective epitopes on the glycoproteins of Venezuelan equine encephalomyelitis virus by passive transfer of monoclonal antibodies. J Immunol 1982, I 29:2763-2767.

37. Roehrig JT, Hunt AR, Kinney RM, Mathews JH: In vitro mechanisms of monoclonal antibody neutralization of alphaviruses. Virology 1988, 1 65:66-73.

38. Hunt AR, Roehrig JT: Localization of a protective epitopeon a Venezuelan equine encephalomyelitis (VEE) virus peptide that protects mice from both epizootic and enzootic VEE virus challengeand is immunogenic in horses. Vaccine 1995, I 3:281-288.

39. Hunt AR, Frederickson S, Hinkel C, Bowdish KS, Roehrig JT: A humanized murine monoclonal antibody protects mice either before or after challenge with virulent Venezuelan equine encephalomyelitis virus. J Gen Virol 2006, 87:2467-2476.

40. Roehrig JT, Mathews JH: The neutralization site on the E2glycoprotein of Venezuelan equine encephalomyelitis (TC-83) virus is composed of multiple conformationally stable epitopes. Virology 1985, I42:347-356.

41. Wang E, Paessler S, Aguilar PV, Smith DR, Coffey LL, Kang W, Pfeffer M, Olson J, Blair PJ, Guevara C, Estrada-Franco J, Weaver SC: A 
novel, rapid assay for detection and differentiation of serotype-specific antibodies to Venezuelan equine encephalitis complex alphaviruses. Am J Trop Med Hyg 2005, 72:805-810.

42. Duggan JM, Coates DM, Ulaeto DO: Isolation of single-chain antibody fragments against venezualan equine encephalomyelitis virus from two different immune sources. Viral Immunol 200I, I 4:263-273.

43. Guo YC, Zhou YF, Zhang XE, Zhang ZP, Qiao YM, Bi LJ, Wen JK, Liang MF, Zhang JB: Phage display mediated immuno-PCR. Nucleic Acids Res 2006, 34:e62.

44. Spearman C: The method of right and wrong cases (constat stimuli) without Gauss formulae. Brit J Psychol 1 908, 2:227-242.

45. Kaerber G: Beitrag zur kollektiven Behandlung pharmakologischer Reihenversuche. Arch Exp Pathol Pharmakol 1931, 1 62:480-483.

46. Berge TO, Banks IS, Tiggert WD: Attenuation of Venezuelan equine encephalomyelitis virus by in vitro cultivation in guinea-pig heart cells. American Journal of Hygiene 1961, 73:209-218

47. Frolov IV, Kolykhalov AA, Volchakov VE, Netesov SV, Sandakhchiev LS: Comparison of the amino acid sequence of structural proteins from attenuated and pathogenic strains of the Venezuelan equine encephalomyelitis virus. Dokl Akad Nauk SSSR |99|, 3 | 8:|488-|49|.

48. Sambrook J, Russell DW, (Eds): Molecular cloning: a laboratory manual. 3rd edition. New York: Cold Spring Harbor Laboratory Press; 200I.

49. Hust M, Toleikis L, Dübel S: Antibody phage display. In Handbook of therapeutic antibodies Edited by: Dübel S. Weinheim: Willey-VCH; 2007:45-68.

50. Pelat T, Hust M, Laffly E, Condemine F, Bottex C, Vidal D, Lefranc MP, Dübel S, Thullier P: A high affinity, human like antibody fragment (scFv) neutralising lethal factor (LF) of Bacillus anthracis by inhibiting the PA-LF complex formation. Antimicro Agents Chem 2007, 5 I:2758-2764.

5I. Rondot S, Koch J, Breitling F, Dübel S: A helper phage to improve single-chain antibody presentation in phage display. Nat Biotechnol 200I, I9(I):75-78.

52. Hust M, Meysing M, Schirrmann T, Selke M, Meens J, Gerlach GF, Dübel S: Enrichment of open reading frames presented on bacteriophage MI3 using Hyperphage. Biotechniques 2006, 4I:335-342.

53. Soltes G, Hust M, Ng KKY, Bansal A, Field J, Stewart DIH, Dübel S, Cha $S$, Wiersma $E$ : On the influence of vector design on antibody phage display. J Biotechnol 2007, I 27(4):626-237.

54. Retter I, Althaus $\mathrm{HH}$, Münch R, Müller W: VBASE2, an integrative V gene database. Nucleic Acids Res 2005, 33(Database issue):D67I-D674.

55. Mollova S, Retter I, Müller W: Visualising the immune repertoire. BMC Systems Biology 2007, I:P30.

56. Kirsch M, Zaman M, Meier D, Dübel S, Hust M: Parameters affecting the display of antibodies on phage. J Immunol Methods 2005 , $301(1$ - 2): I73-185.

57. Li J, Menzel C, Meier D, Zhang C, Dübel S, Jostock T: A comparative study of different vector designs for the mammalian expression of recombinant IgG antibodies. I Immunol Methods 2007, 3 I 8( I - 2): | | 3-124
Publish with Bio Med Central and every scientist can read your work free of charge

"BioMed Central will be the most significant development for disseminating the results of biomedical research in our lifetime. "

Sir Paul Nurse, Cancer Research UK

Your research papers will be:

- available free of charge to the entire biomedical community

- peer reviewed and published immediately upon acceptance

- cited in PubMed and archived on PubMed Central

- yours - you keep the copyright
BioMedcentral 